\title{
Problems of sustainable development in the state (regional) economic security in the context of cycling economy
}

\author{
Daniil Beloshitskii ${ }^{1}$, and Oleg Patlasov ${ }^{1,2, *}$ \\ ${ }^{1}$ Omsk Humanitarian Academy, 4th Cheluskintsev st., 2a, 644144 Omsk, Russia \\ ${ }^{2}$ Smolensk state agricultural Academy, The Great Soviet, 10/2, 214000 Smolensk, Russia
}

\begin{abstract}
The article considers the problems of sustainable economic development. Based on the array of studied information, the authors have proposed a definition of sustainable development. Sustainable economic development has been proved to be impossible in the long term and the peripheral countries. Our research has identified the main principles necessary for building a sustainable development policy, as well as problems that thwart sustainable development goals. As a conclusion, we should state that immature and inconsistent technological processes in the periphery countries make the quick transition to sustainable development impossible.
\end{abstract}

\section{Introduction}

Sustainable development is the harmonious development of the economy that meets the present needs without prejudice to future generations, with an emphasis on interaction with environmental and social factors.

Sustainable economic development closely correlates with the economic security of countries and regions. A well-established system of economic security prevents in advance negative processes affecting the economy of the subjects. The concept of sustainable economic development has faced more criticism among economists and scientists. The forward movement of the economy of the region, the country, the world economy is cyclical, with the compression of all economic cycles (J. Kitchin, C. Juglar, S. Kuznets, N. Kondratiev, J. Forrester, A. Toffler).

The situation can occur against the background of natural disasters, pandemics, political upheavals, demographic factors, etc. Sustainable development is not associated with surges in economic indicators, including growth, which determines its sharp economic rises.

In pursuit of economic sustainability, countries and regions, based on the UN goals, link to socio-economic and environmental factors, which neglects problems of other areas, solving a deep and constructive scientific dialogue.

The limiting factor for sustainable economic growth is the high total debt burden, which prevents a quick recovery. The cyclical nature has been studied in the scientific literature,

\footnotetext{
*Corresponding author: opatlasov@mail.ru
} 
but the new reality of the digital economy makes it difficult to predict the intensity of the crisis and the speed of progress through the phases of the cycles.

\section{Materials and methods}

To study the nature of "economic stability" as one of the components of economic security, we have studied its typology [1]. The scientific economic literature provides the generalized grouping of definitions of sustainable development according to 3 criteria: the ability of an economic entity to withstand external disturbances for a long time; setting stabilizing tasks by regulators; achieving a close-to-equilibrium state of economic agents. In our opinion, equilibrium theories are exclusively academic with significant restrictions, and complete equilibrium is impossible both at the macro and micro level. Austrian economist $\mathrm{J}$. Schumpeter determined the amplitude of macroeconomic fluctuations based on the "threecycle scheme" of economic changes, which has combined half-century, medium-term and short-term cycles [2. Some researchers also link economic processes with the change of the civilizational pyramid [3].

The applied methods for the cyclical and sustainable analysis of economic objects include wave methods, spectral method, morphological analysis, Markoff process, methods of trend detection, smoothing, and decomposition of time series, as well as analysis of leading indicators, which is used in the study of cyclical fluctuations.

According to the OECD (Organization for Economic Co-operation and Development) and CIBCR (Center for International Business Cycle Research) methodology, the most significant leading indicators are the price index, the amount of cash in circulation, loan rates, stock exchange indices, stocks, and housing development (Table 2). To analyze cyclical fluctuations, the profit of the enterprise, the length of the working day, and indicators of industrial production are distinguished.

Table 1. Classification of cyclical development indicators, the US National Bureau of Economic Research.

\begin{tabular}{|c|c|c|}
\hline Leading indicators & Lagging indicators & Coincident indicators \\
\hline Hours worked & Number of long-term unemployed citizens & GDP \\
\hline $\begin{array}{l}\text { Number of new } \\
\text { (established) enterprises }\end{array}$ & New job and enterprise creation costs & Unemployment rate \\
\hline $\begin{array}{l}\text { Start of residential } \\
\text { development }\end{array}$ & Payroll expenses & Industrial production \\
\hline Stock market indices & $\begin{array}{l}\text { Average interest rates of commercial } \\
\text { banks }\end{array}$ & Personal income \\
\hline Corporate profit & \multirow{3}{*}{ Number of long-term unemployed citizens } & Producer prices \\
\hline Inventory change & & Applications for \\
\hline Money supply change & & advertisements \\
\hline
\end{tabular}

Source: National Bureau of Economic Researches

The need to explore financial crises and the consequences of political actions that affect economic fluctuations and growth has allowed for a more detailed study of heterogeneous agent-based models. The heterogeneous agent-based model makes it possible to better cover the mechanism for introducing monetary policy and to trace its distributional consequences [4].

The literature review has shown urbanization and industrialization in developing countries to be a serious problem on the path to sustainable economic development, with environmental protection as its central element [5]. 
The main analytical material for economic sustainability is the sustainable development goals stated in the UN agenda. In most of the analyzed materials, the authors use the "matrix of influence" to identify the main directions of sustainable development goals.

Multiple analysis has evolved significantly in recent years. It became apparent that complex social phenomena must be considered to identify vulnerabilities. During the research, a holistic and transdisciplinary approach was used together with critical analysis and descriptive and deductive-inductive methods.

To find the link between economic and non-economic aspects that affect sustainable development, we have structurally systematized and combined various ideas found in the scientific literature.

\section{Hypotheses}

Hypothesis 1: Does the introduction and improvement of sustainable economic development affect the economic security of the country (region)?

Hypothesis 2: Is sustainable economic development possible in the long term if the global priorities of the civilization pyramid change?

Hypothesis 3: Can centralized management (manual management) transform the economy towards sustainable development, especially in Asian countries with a special socio-cultural background?

Hypothesis 4: What is the role of public corporations in technological breakthroughs?

Hypothesis 5: Does the introduction of a cyclic economy improves the economic benefits of the world, country, region, company?

\section{Results and discussion}

In the context of a recession associated with a pandemic, instruments of microeconomic stabilization are provoking a particular interest.

The post-industrial development scale has the following types of economies distinguished: information, knowledge economy, network, sharing economy, digital, creative, green, and cyclic economy.

In peripheral countries, the idea of sustainable development is linked to the issue of sustainable (rational) consumption. Developing countries in their race for sustainable development, due to a weak processing base and lack of necessary technologies, cannot organize efficient consumption, which leads to the irrational use of material resources [6].

Another no less important factor that affects sustainable consumption is the level of demographic development. An increase in the population, as well as depopulation, leading to a reduction in the labor force and labor potential, is one of the main socio-demographic problems that affect both sustainable production and consumption [7].

The sustainable development goals are reflected in the 2030 UN Agenda for Sustainable Development [8]. The agenda contains 17 goals that will contribute to ending poverty, improving human well-being, and protecting the planet. A particular focus of sustainable development is on the relationship between the environment and economic growth. 


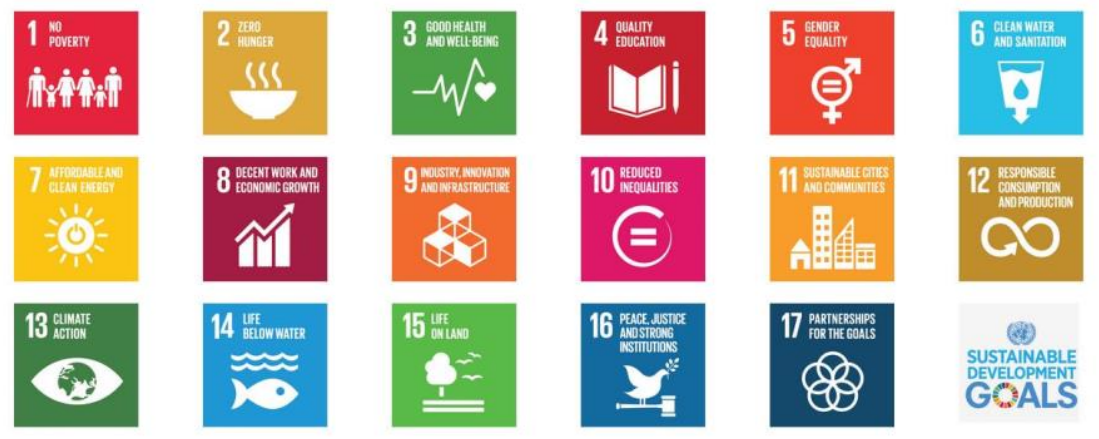

Fig.1. UN Sustainable Development Goals.

States have recognized the need for a balanced social policy aimed at sustainable economic growth to achieve all the goals set [9].

Social benefits obtained from the sustainable development goals, implying a transition to sustainable energy systems and materials, will allow regions to improve their economic, social, and environmental security and safety [10].

Finding solutions to environmental problems and economic growth is no news. Representatives of the neoclassical school were the first to try to solve this problem. One of their points of view was based on a biophysical approach, i.e. economic growth leads to a deterioration in the environment due to the growing consumption of materials (minerals) [11].

Focusing on ecology and rational use of minerals only avoids economic sustainability because modern production operates non-renewable materials and energy sources.

One of the essential aspects of sustainable economic development is the crisis factor, which cannot be sustainable. This is due to the cyclical nature of crises in the state and global economies. Long-term maintenance of an interconnected, balanced supply and demand system on a global scale is an unfeasible task. Thus, the Russian economy experienced three crises: the Asian crisis in 1998, the global (world) financial crisis in 2008 , and the "health care" crisis in 2020.

World practice shows that each economic system, either of an individual country or global, evolves from order to house [12], and requires a scientific explanation of the phenomenon of controlled chaos.

There are different opinions about the causes and duration of economic cycles at the macro and micro levels. The most famous cyclical systems in the economic literature are as follows:

Table 2. Types of economic cycles.

\begin{tabular}{|c|c|l|l|}
\hline $\begin{array}{c}\text { Main } \\
\text { types of } \\
\text { economic } \\
\text { cycles }\end{array}$ & $\begin{array}{c}\text { Cycle } \\
\text { duration }\end{array}$ & \multicolumn{1}{|c|}{ Feature } & \multicolumn{1}{|c|}{ Source } \\
\hline J. Kitchin & $2-4$ & $\begin{array}{l}\text { Temporary fluctuations are caused } \\
\text { by the delay between making a } \\
\text { decision and receiving the } \\
\text { necessary information. The cycle is } \\
\text { driven by fluctuations in stocks. }\end{array}$ & $\begin{array}{l}\text { Kitchin J. Cycles and Trends in Economic } \\
\text { Factors. Review of Economics and } \\
\text { Statistics 5 (1): 10-16. 1923. }\end{array}$ \\
\hline C. Juglar & $7-12$ & $\begin{array}{l}\text { Wave fluctuations are caused by } \\
\text { the inflow of investments and the } \\
\text { renewal of fixed assets, which } \\
\text { contribute to the growth and the } \\
\text { following fall after the depreciation } \\
\text { of fixed assets }\end{array}$ & $\begin{array}{l}\text { Juglar C. Des Crises Commercials Et De } \\
\text { Leur Retour Periodique En France. Paris, } \\
\text { 1862. 4. Schumpeter J. Business Cycles: A } \\
\text { Theoretical, Historical and Statistical } \\
\text { Analysis of the Capitalist Process. N.Y.-L., } \\
1939 .\end{array}$
\end{tabular}


Table 2. Continued.

\begin{tabular}{|c|c|c|c|}
\hline S. Kuznets & $16-25$ & $\begin{array}{l}\text { Fluctuations are based on migration } \\
\text { flows, mainly in the construction } \\
\text { industry, as well as investment in } \\
\text { the construction industry. }\end{array}$ & $\begin{array}{l}\text { Kuznets S. Secular Movements in } \\
\text { Production and Prices. Their Nature and } \\
\text { their Bearing upon Cyclical Fluctuations. } \\
\text { Boston: Houghton Mifflin, } 1930 .\end{array}$ \\
\hline $\begin{array}{c}\mathrm{N} . \\
\text { Kondratiev }\end{array}$ & $40-60$ & $\begin{array}{l}\text { The main reason is radical changes } \\
\text { in production technology and its } \\
\text { restructuring. }\end{array}$ & $\begin{array}{l}\text { Kondratiev N.D. Major conjuncture cycles } \\
\text { and the theory of foresight. Selected works } \\
\text { / ed. Iu.V. Iakovets, L.I. Abalkin. M.: } \\
\text { Economics, } 2002 \text {. } \\
\text { Kondrat'ev N.D. Osnovnye problemy } \\
\text { jekonomicheskoj statiki i dinamiki. M.: } \\
\text { Nauka, 1991. } 570 \text { p. } 6 \text {. Kondrat'ev N.D. } \\
\text { Problemy jekonomicheskoj dinamiki. M.: } \\
\text { Jekonomika, } 1989.525 \text { p. } 7 \text {. }\end{array}$ \\
\hline J. Forrester & 200 & $\begin{array}{l}\text { The cycle is associated with the } \\
\text { transition to more advanced } \\
\text { resources and energy sources. } \\
\text { The cycle is determined by } 5 \\
\text { indicators: the population of the } \\
\text { Earth; natural resource stocks; food } \\
\text { production; environmental } \\
\text { pollution; and investments. Capital } \\
\text { investments are understood as } \\
\text { funds that characterize the level of } \\
\text { economic development that } \\
\text { transform the nature }\end{array}$ & $\begin{array}{l}\text { Forrester Dzh. Dinamika razvitija goroda. } \\
\text { M.: Progress, 1974. } 288 \text { p. } 9 .\end{array}$ \\
\hline A. Toffler & $\begin{array}{c}1000- \\
2000\end{array}$ & $\begin{array}{l}\text { Civilization waves caused by three } \\
\text { stages of human development, i.e. } \\
\text { agrarian, industrial, and post- } \\
\text { industrial, in the history of } \\
\text { mankind: 1st wave - } 8-9 \text { thousand } \\
\text { years ago - the Neolithic revolution, } \\
\text { which gave birth to an agricultural } \\
\text { civilization; 2nd wave - XVIII-XIX } \\
\text { centuries - industrial civilization - } \\
\text { the destruction of the then existing } \\
\text { society and the origination of a new } \\
\text { civilization as a result of the } \\
\text { industrial revolution; 3rd wave - } \\
\text { late } 20 \text { th century - a new way of } \\
\text { life, a new society is being formed, } \\
\text { the main feature is the transition to } \\
\text { renewable energy sources. }\end{array}$ & $\begin{array}{l}\text { Alvin Toffler (1980): The Third } \\
\text { WaveToronto. Bantam Books. } 537 \text { pages }\end{array}$ \\
\hline
\end{tabular}

The cyclical nature of crisis processes shows the incorrect setting of goals for sustainable economic development, making it a deliberately unfeasible task. Each UN goal requires its detailed study, which will minimize cyclical processes but not get rid of them.

When developing a policy for sustainable development goals, the governments of countries and regions should focus on and strive for circular economic processes, as well as rely on the principles that are fundamental for this direction [13].

The basic principles of a circular economy include:

-Self-adaptive, circular processes capable of integrating both spatially and temporally.

-Effective use of biological resources and support of their viability.

-Refusal to use non-renewable materials.

-Improvement of public well-being.

-Consolidation of both regional and global actions in sustainable development.

-Development of the relationship between the elements of production potential, consisting of their technical, human, natural, and intellectual capital.

-Balance between sustainable consumption and production. 
-Development of the institution of justice by gender, age, race, ethnicity, and religion.

Sustainable development is formed from a variety of complex, interconnected spheres of life of society and the economy that developed under the principles of fundamental goods and common values (Figure 2) [14].

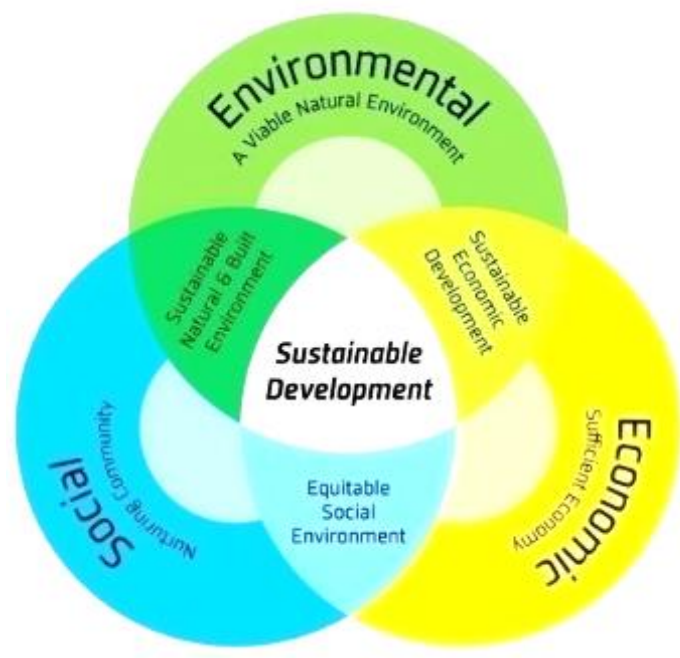

Fig. 2. Sustainable development of social, environmental, and economic systems.

Subject to the multidimensional nature of sustainable development, a progressive view must be formed in terms of economic security to identify radical and conservative forms of foreign hegemony and local oligarchy.

Considering the concept of sustainable development as constantly evolving, we have found the need to determine its practical sides through measurable indicators.

There is a huge variety of methods for finding the level of sustainable development, developed by both international organizations and scientific figures, but no single accepted one. The World Health Organization proposes multicriteria analysis for several measurement systems whose indicators are either insufficiently objective or clearly defined. They are monetary and are calculated based on market prices (competitiveness, quality of management, environmental and economic accounting).

To avoid wrong, misleading results, the Organization for Economic Co-operation and Development, in collaboration with the Joint Research Center of the European Commission, has developed a ten-step methodological framework that includes aggregated indicators for different areas.

The mathematical task of each technique is to solve the problems typical of a particular field of activity. The main destabilizing problems of the economy include:

- Surges in prices for food and energy resources (fixed price is a difficult task in market relations, where the price is directly dependent on supply and demand and the country's entry into various organizations, such as WTO, EU, NAFTA, ASEAN);

- Overexploitation of natural resources (large companies, using the corruption of the authorities, destroy biodiversity, for example, oil companies are destroying the forests of Ecuador to develop new oil production sites);

- Explosive population growth (an increase in the population number leads to an increase in the consumption of the planet's resources, which in turn affects sustainable consumption and leads to the depletion of biological resources);

- Large financial costs for the energy sector (peripheral countries need to modernize the energy sector to bring it in line with modern standards and the switch to green energy) 
As technology develops, the cyclic economy is gaining more popularity, which aims to put materials, products, and components on a loop, where they can be returned to the value chain at the end of their service life, to ensure minimal loss of their value.

\section{Conclusions}

Achieving sustainable economic development is closely related to sustainable consumption. Minimization of the crisis consequences requires a well-functioning system of economic security, which can predict economic collapse and protect the economies of countries and individual regions from disastrous consequences.

Such a system cannot develop centrally using common criteria and indicators.

A rapid transition to sustainable development is impossible due to the immature and inconsistent technological processes unable to rebuild to new formats of socio-technical changes, which have made a step forward along the development curve for several years ahead.

The study of the multilevel complexity and intersection of areas of sustainable economic development has revealed the need to create a regenerative-adaptive paradigm that would collect the best global practices and simulate a single sustainable worldview [15].

Countries that have already formed economic potential, such as the PRC, are currently forced to focus on the environmental component. Experiencing negative environmental processes that pose a threat to both the public health and the natural balance, Chinese applicants begin to show an increasing interest in environmental management [16].

Early in its development, China mainly used cheap labor and waste of the United States, while now, having a solid gold and foreign exchange reserve, it has moved to a sustainable (lean) economy.

Having studied the cyclical economic processes in the economy we concluded about the inability to achieve sustainable economic growth in the long term, associated with manmade and natural disasters and financial crises.

\section{References}

1. D. S. Beloshitskii, O. Iu. Patlasov, Human Science: Humanities Research, 1(39), 195 (2020)

2. A. Joseph, Schumpeter, History of Economic Analysis: With a New Introduction 2nd ed. Edition, http://digamo.free.fr

3. O. Yu. Patlasov, Cultural and Environmental Priorities International Journal of Ecology \& Development, 32(3), 86 (2017)

4. M. Gertler, P. Klenov, Program Report: Economic Fluctuations and Growth, https://www.nber.org

5. T. M Baynes, D. B. Müller, A Socio-economic Metabolism Approach to Sustainable Development and Climate Change Mitigation (2016)

6. F. Quoquab, N. N. Sukari, Why Sustainable Consumption Is Not in Practice? A Developing Country Perspective (2017)

7. V. V. Karpov, K. V. Petrenko, P. A. Dubovenko, Human Science: Humanities Research, 14(4), 186 (2020)

8. Transforming our world: the 2030 Agenda for Sustainable Development, https://sustainabledevelopment.un.org 
9. S. E. Bibri, Eur J Futures Res., 6, 13 (2018)

10. S. M. McCauley, J. C. Stephens, Sustain Sci, 7, 213 (2012)

11. V. Andreoni, J Glob Policy Gov., 1, 185 (2013)

12. M. Bormotov, Economic cycles: historical evidence, classification and explication, https://mpra.ub.uni-muenchen.de

13. K. Sriram, L.S. Ganesh, R. Madhumathi, IIMB Management Review, 25(1), 36 (2013)

14. I. Christie, R.M. Gunton, A.P. Hejnowicz, Sustainability and the common good: Catholic Social Teaching and 'Integral Ecology' as contributions to a framework of social values for sustainability transitions. Sustain Sci, 14, 1343 (2019)

15. P. B. Roös, The Importance of a Sustainable Future (2021)

16. O. Yu. Patlasov, Ye. K. Zharov, International Journal of Ecological Economics and Statistics, 38(3), 134 (2017) http://www.ceser.in 